\title{
Relasi Antara Investor Pariwisata Dengan Masyarakat Lokal Di Desa Pakraman Laplapan Desa Petulu Kecamatan Ubud (Studi Kasus Konflik Sosial)
}

I Ketut Agus Gita Suprapta a, 1, I Gusti Agung Oka Mahagangga a, 2

1agus.suprapta25@gmail.com,2 okamahagangga@unud.ac.id

a Program Studi S1 Destinasi Pariwisata, Fakultas Pariwisata,Universitas Udayana, Jl. Dr. R. Goris, Denpasar, Bali 80232 Indonesia

\section{Abstract}

The research titled is "relationship between tourism investors and lokal communities in Desa Pakraman Laplapan Petulu Village (Case Study Social Conflict)", purpose to understand the relationship undertaken by tourism investors with lokal communities that happened in the Ubud tourist destination.

Data were collected through observation, interview and literature study. Infoman taken by purposive, which determine the informan with a certain considerations that are considered able to provide data to the maximum in accordance with the criteria of the research objectives. The collected data were analyzed descriptively qualitative. An important concept in the study include the concept of Typology Relations Styling in 3 Zone which consists of the outer zone, the middle zone and center zone.

The results of this study indicate that, Desa Pakraman Laplapan as a region lies in the outer zone. Relationships that lived between tourism investors and lokal communities in Desa Pakraman Laplapan patterned conflictual. This pattern is shown by the regulation provided by the lokal community to tourism investors who are less rational. As for the view of the conflict is a way to snatch for limited resources. And one of them is the economic resource owned by the investor. Styling tourism investor relations with the lokal community in Desa Pakraman Laplapan has been sticking to the surface of the endless conflict. In this case, the farmer must make good relationship with tourism investors because it would help to farmers.

Keywords: Relationship, Investors, Lokal Communities, Conflict

\section{PENDAHULUAN}

Ubud merupakan salah satu daerah tujuan wisata di Bali yang mengalami perkembangan yang sangat pesat. Perkembangan pariwisata yang terjadi di Ubud ditandai dengan pertumbuhan investor pariwisata yang semakin meningkat. Salah satu tanda dari perkembangan pariwisata di Ubud diketahui dari jumlah usaha akomodasi pariwisata di Kecamatan Ubud dari tahun 2010 sampai dengan tahun 2014 terus meningkat yang diikuti pula dengan meningkatnya jumlah kunjungan wisatawan ke Ubud.

Terdapat tiga pilar utama dalam pariwisata (Suwena dan Widyatmaja, 2010) meliputi, pemerintah dan investor serta masyarakat lokal. Adapun interaksi yang terjadi menimbulkan relasi saling menjalin terjadi didalamnya. Dalam perkembangannya, kehadiran investor dalam mengelola sumber daya pariwisata yang dimiliki oleh masyarakat lokal sering menemui hambatan. Masyarakat lokal dengan sumber daya manusia mengenai pariwisata yang minim sering menjadi kendala bagi investor.

Relasi yang baik perlu dibangun antara investor pariwisata dengan masyarakat lokal. Investor pariwisata dituntut untuk membangun relasi dengan masyarakat lokal dengan situasi dan kondisi di lapangan. Namun pada realitasnya, pola pikir masyarakat lokal menjadi tantangan bagi investor pariwisata dalam menjalin relasi yang berkelanjutan. Berdasarkan latar belakang yang telah disampaikan, adapun tujuan dalam penelitian ini adalah untuk memahami relasi antara investor pariwisata dengan masyarakat lokal di Desa Pakraman Laplapan khususnya dalam relasi sosial ekonomi.

\section{TINJAUAN PUSTAKA}

Adapun penelusuran yang telah dilakukan oleh peneliti berkaitan dengan penelitian ini menemukan bahwa adanya penelitian yang berkaitan dengan relasi investor pariwisata dengan masyarakat lokal khususnya petani. Penelitian (Hartati et al, 2013) yang menyatakan bahwa, relasi antara investor dan petani berjalan secara bersinergi dan memberikan dampak positif terhadap kedua belah pihak.

Disisi lain, hasil yang berbeda ditemui dalam penelitian (Asikin, 2014) mengenai investor pariwisata dengan petani. Penelitian (Asikin, 2014) tersebut mengkaji mengenai 
konflik pertanahan dengan permasalahan yang bersumber pada pelayanan khusus yang diberikan pemerintah kepada investor.

Penelitian ini adalah studi kasus konflik sosial yang pernah terjadi di daerah tujuan wisata Ubud. Adanya hubungan yang disharmoni antara investor pariwisata dengan petani Desa Pakraman Laplapan terjadi tanpa adanya campur tangan dari pemerintah dalam permasalahan yang terjadi.

Dalam penelitian ini menggunakan beberapa teori dan konsep yang bertujuan untuk menyederhanakan permasalahan yang ditelusuri dalam penelitian meliputi teori Konflik (Coser dalam Soekanto, 1990), teori Strategi Penyelesain Konflik (Wilson dan Ryland dalam Wahyu, 1986), konsep Pemicu Konflik Sosial (Tuner dalam Setiadi dan Kolip, 2011), dan konsep Aktor Pariwisata (Suwena dan Widyatmaja, 2010) serta konsep Tipologi Corak Hubungan dalam Tiga Zone dari (Arida dalam Putra dan Pitana, 2011).

\section{METODE PENELITIAN}

Penelitian ini berlokasi di Kecamatan Ubud, Kabupaten Gianyar yang terfokus pada lokasi yang lebih mengkhusus yaitu Desa Pakraman Laplapan Desa Petulu. Ruang lingkup penelitian ini adalah relasi yang dijalani oleh investor dengan masyarakat lokal Desa Pakraman Laplapan akan dianalisis dengan konsep Tipologi Corak Hubungan Tiga Zone (Arida dalam Putra dan Pitana, 2011).

Teknik pengumpulan data yang digunakan dalam penelitian ini adalah wawancara mendalam, observasi, dokumentasi dan studi kepustakaan yang berkaitan dengan penelitian ini. Teknik penentuan informan dalam penelitian ini menggunakan teknik Purposive Sampling, dan menjadi subjek penelitian meliputi: Investor asing, Bendesa Adat Desa Pakraman Laplapan dan beberapa anggota Desa Pakraman Laplapan.

Teknik analisis yang digunakan dalam penelitian ini menggunakan analisis data kualitatif. Sugiyono (2013) menyatakan bahwa, analisis data kualitatif adalah bersifat induktif yaitu pola hubungan tertentu maupun hipotesis terjadi dari analisa berdasarkan data yang telah diperoleh di lapangan. Dalam penelitian ini, data yang terkumpul dianalisis kemudian dikembangkan pola hubungan tertentu sehingga memenuhi tujuan awal penelitian.

\section{HASIL DAN PEMBAHASAN}

Ubud merupakan daerah tujuan wisata yang banyak digemari oleh wisatawan mancanegara maupun lokal. Ubud terdiri dari berbagai desa yang tergabung di dalamnya. Salah satu desa yang tergabung dalam Kecamatan Ubud adalah Desa Petulu. Desa Petulu merupakan bagian dari Kecamatan Ubud dan merupakan bagian dari kawasan daerah tujuan wisata Ubud serta memiliki atraksi yang mendukung kegiatan kepariwisataan yang ada di Ubud. Salah satu atraksi yang ada di Desa Petulu yaitu atraksi Wisata Kokokan. Desa Petulu terdiri dari enam desa pakraman yakni : Desa Pakraman Petulu Gunung, Desa Pakraman Petulu Desa, Desa Pakraman Kutuh Kaja, Desa Pakraman Kutuh Kelod, Desa Pakraman Nagi, dan Desa Pakraman Laplapan. Desa - desa Pakraman tersebut tergabung ke dalam Desa Petulu.

Adapun dampak pertumbuhan pariwisata yang terjadi dan dirasakan setiap desa pakraman yang tergabung dalam Desa Petulu yang berasal dari perkembangan daerah tujuan wisata Ubud. Salah satu dari desa pakraman yang merasakan adanya dampak pariwisata di Desa Petulu adalah Desa Pakraman Nagi dengan batas wilayah timur berbatasan dengan Desa Pakraman Laplapan, sebelah utara berbatasan dengan Desa Pakraman Petulu Desa, sebelah barat berbatasan dengan Desa Peliatan, sebelah selatan berbatasan dengan Desa Peliatan. Perkembangan pariwisata yang terjadi di Desa Pakraman Nagi ditandai dengan adanya investor pariwisata yang menanamkan modalnya disana.

Investor pariwisata dalam penelitian ini merupakan penanam modal asing yang bergerak di bidang usaha jasa pariwisata yang bergerak dalam jasa sarana penunjang pariwisata yakni akomodasi pariwisata yang terletak di daerah tujuan wisata Ubud. Akomodasi pariwisata tersebut berdiri dengan nama sebagai Hotel Viceroy yang dimiliki oleh PT. Lembah Maharaja yang berlokasikan di Desa Pakraman Nagi.

Desa Pakraman Nagi termasuk kedalam kawasan Daerah Tujuan Wisata Ubud. Investor pariwisata tersebut memiliki relasi dengan masyarakat lokal Desa Pakraman Nagi. Pada dasarnya, lokasi pembangunan maupun posisi dari Hotel Viceroy mengarah ke Desa 
Pakraman Lapalapan. Posisi hotel yang merupakan daerah perbatasan antara Desa Pakraman Nagi dengan Desa Pakraman Laplapan namun, lokasi hotel tersebut masih dimiliki oleh Desa Pakraman Nagi.

Secara tidak langsung, posisi hotel telah menggunakan sumber daya alam berupa landscape yang dimiliki oleh Desa Pakraman Laplapan oleh karena posisi hotel berda di pinggiran sungai Petanu yang merupakan batas wilayah yang membelah Desa Pakraman Nagi dengan Desa Laplapan.

Adapun bentuk - bentuk kerjasama yang terjalin antara masyarakat Desa Pakraman Nagi dengan investor pariwisata yaitu salah satunya kerjasama dalam bidang ketenaga kerjaan. Masyarakat Desa Pakraman Nagi diprioritaskan sebagai karyawan di Hotel Viceroy serta adanya sistem sewa lahan yang dimiliki oleh krama Desa Pakraman Nagi sebagai akses menuju ke lokasi hotel oleh karena lahan tersebut dimiliki oleh Desa Pakraman Nagi.

Seiring dengan perkembangan yang terjadi, hotel tersebut memerlukan lingkungan disekitar lokasi hotel tetap terjaga kealamiannya. Adanya lahan masyarakat dari desa tetangga dijadikan sebagai indikator pendukung dalam value jasa yang dipasarkan. Tidak adanya kerjasama yang terjalin antara pihak investor pariwisata dengan Desa Pakraman Laplapan, untuk mengantisapasi terjadinya alih fungsi lahan pertanian di desa tetangga yakni Desa Pakraman Laplapan, pihak hotel maupun investor pariwisata mengambil tindakan dengan melakukan sistem sewa lahan dengan beberapa petani yang memiliki lahan berdekatan maupun bersebelahan dengan lokasi hotel.

Isu sistem sewa lahan tersebut merambat ke semua petani khususnya petani yang memiliki lahan tegalan yang bersebelahan dengan penerima sistem sewa lahan. Aksi petani untuk pengajuan mendapatkan hal yang sama dengan petani yang menerima sistem sewa lahan berujung konflik. Konflik tersebut terjadi dari adanya kecemburuan sosial yang terjadi diantara petani pemilik lahan yang berdekatan dengan lahan hotel yang dimiliki oleh investor pariwisata.

Adapun kepentingan ekonomi yang timbul dari setiap petani pemilik lahan akan sumber daya yang terbatas memicu terjadinya konflik.
Dalam kasusnya, hubungan kerjasama yang tercipta antara investor pariwisata dengan petani dari Desa Pakraman Laplapan yang berujung konflik dipengaruhi dari regulasi yang diterapkan di Desa Pakraman Laplapan yang kurang rasional dilakukan. Salah satu bentuk regulasinya yakni Penyerapan tenaga kerja lokal harus mencapai 40\%.

Pemetaan relasi yang terjadi antara investor pariwisata dengan masyarakat Desa Pakraman Laplapan dapat disederhanakan dengan konsep Tipologi Corak Hubungan Tiga Zone (Arida dalam Putra dan Pitana, 2011). Penentuan alternatif dalam pembagian zonasi yang dapat dituangkan dalam gambar seperti berikut:

\section{Gambar 4.1}

Tipologi Corak Hubungan dalam 3 Zone

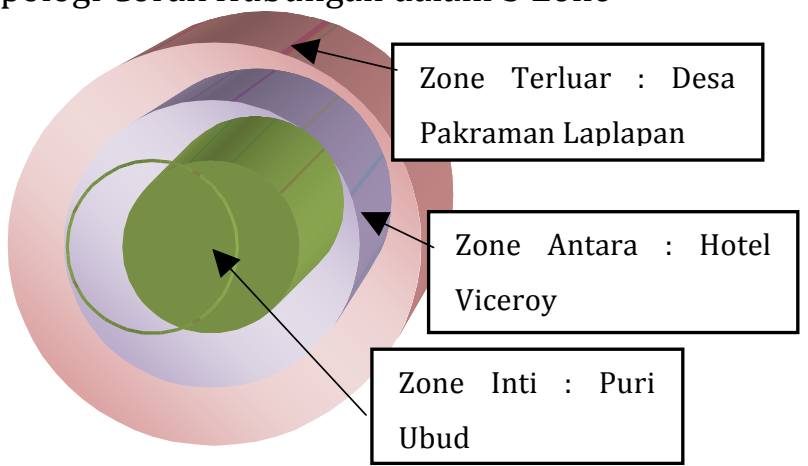

Sumber : Hasil Penelitian 2015.

Bedasarkan gambar 4.1, Posisi dari hotel Viceroy termasuk dalam kategori Zone Antara. Zone Ini yang menghubungkan Zone Inti dengan Zone Terluar. Di dalam Zone Antara, masyarakat Desa Pakraman Nagi sebagai tuan rumah bagi Hotel Viceroy memiliki pola hubungan dengan Hotel Viceroy yang dimiliki oleh investor dalam memenuhi sumber daya manusia yang diperlukan oleh hotel, serta Desa Pakraman Nagi memiliki kerjasama dalam beberapa hal yang berkaitan dengan keperluan hotel pada waktu tertentu,

Dalam kaitannya ditinjau dari segi lokasi, Desa Pakraman Laplapan terletak di zone terluar dalam kawasan daerah tujuan wisata Ubud. Desa Pakraman Laplapan cenderung memiliki pola hubungan yang kurang rasional. Hal ini ditandai dengan adanya regulasi yang kurang rasional diberikan kepada investor.

Secara garis besarnya, sejalan dengan penelitian yang dilakukan (Arida dalam Putra dan Pitana, 2011) mengenai relasi investor 
dengan desa pekraman di Desa Ubud, bahwa desa yang termasuk zone terluar memiliki gaya berhubungan yang konfliktual. Dari analisis pemetaan kawasan berdasarkan zonasi tersebut diketahui bahwa, semakin jauh wilayah penanam modal pariwisata dari Puri Ubud sebagai episentrum maka corak respon hubungan yang diterima bercorak konfliktual dimana desa menjadi instrumen negoisasi yang dilakukan.

Dalam penelitian ini, bentuk dari hubungan yang kurang rasional dijalani oleh masyarakat Desa Pakraman Laplapan dengan investor salah satu diantaranya adalah investor dituntut untuk memberdayakan masyarakat lokal Laplapan sebanyak $40 \%$ dari jumlah keseluruhan tenaga kerja yang diberdayakan namun tidak dibarengi dengan kualitas sumber daya manusia yang berkompeten dimiliki oleh Desa Pakraman Laplapan. Hal ini yang akan memicu konflik yang terjadi antara investor dengan masyarakat lokal.

Adapun pandangan masyarakat Desa Pakraman Laplapan yang beranggapan bahwa konflik merupakan jalan untuk mencapai tujuan mereka dalam merebut sumber daya ekonomi yang dimiliki oleh investor akan menyebabkan timbulnya motivasi konflik yang muncul dari dalam diri masyarakat Desa Pakraman Laplapan.

\section{SIMPULAN DAN SARAN}

\subsection{Simpulan}

Berdasarkan hasil dari pembahasan penelitian, dapat disimpulkan bahwa :

Desa Pakraman Laplapan merupakan wilayah yang termasuk dalam kawasan pariwisata Ubud. Desa Pakraman Laplapan merupakan desa yang terletak di zone terluar yang dipetakan dengan konsep dari Arida (2011). Desa Pakraman Laplapan memiliki corak hubungan yang konfliktual dengan investor. Hal ini ditandai dengan regulasi yang diberikan kepada investor yang kurang rasional. Adapun faktor yang memicu konflik yang terjadinya antara Investor Pariwisata dengan Masyarakat Lokal di Desa Pakraman Laplapan khususnya petani pemilik lahan, salah satunya disebabkan dari adanya faktor ekonomi dalam kasus perebutan sumber daya ekonomi yang terbatas yang dimiliki oleh investor pariwisata. Adanya tuntutan dari desa Pakraman Laplapan kepada investor untuk memberdayakan masyarakat lokal sebesar $40 \%$ dari total karyawan.

\subsection{Saran}

Adapun saran yang dapat diberikan dalam penelitian ini meliputi:

1. Untuk masyarakat lokal Desa Pakraman Laplapan diharapkan untuk mensosialisasikan regulasi yang telah disepakati bersama kepada investor terlebih dahulu. Hal ini bertujuan untuk meminimalisir terjadinya konflik antara investor dengan masyarakat lokal Desa Pakraman Laplapan.

2. Untuk investor diharapkan untuk membangun relasi yang baik dengan masyarakat lokal demi kelancaran bersama.

3. Begitupula kepada akademisi diharapkan memberikan masukan kepada masyarakat Bali khususnya Desa Pakraman Laplapan akan pentingnya menjalin relasi yang baik dengan investor.

Daftar Pustaka:

Putra, Nyoman Darma dan I Gde Pitana. 2011.Pemberdayaan dan Hiperdemokrasi dalam Pembangunan Pariwisata : Persembahan untuk Prof. Ida Bagus Adnyana Manuaba. Denpasar : Pustaka Larasan.

Setiadi dan Kolip. 2010. Pengantar Sosiologi. Pemahaman Fakta dan Gejala Permasalahan Sosial : Teori, Aplikasi Dan Pemecahan. Bandung : Kencana Prenada Media Group.

Soekanto, Soerjono. 1990. Sosiologi Suatu Pengantar. Jakarta : PT. Raja Gravindo Persada.

Sugiyono, 2013. Metode Penelitian Kuantitatif, Kualitatif, dan $R \& D$ (Research and Development). Bandung : Alfabeta.

Suteja, I Made Dharma. 2003. Konflik Kepentingan dalam Pembangunan Pariwisata, Studi Kasus Garuda Wisnu Kencana Culture Park di Desa Ungasan Kecamatan Kuta Selatan Kabupaten Badung Bali. Denpasar : Tesis Program Pascasarjana Universitas Udayana.

Suwena dan Widyatmaja. Pengetahuan Dasar Ilmu Pariwisata. Denpasar. Udayana Press.

Wahyu, 1986. Wawasan Ilmu Dasar.Surabaya : Usaha Nasional.

Sumber Lain.

Pendataan Jasa Sarana Pariwisata Lainnya Kabupaten Gianyar. 2014 . Pemerintah Kabupaten Gianyar Dinas Pariwisata.

\section{Sumber Internet :}

Asikin, Zainal.(2014, June 25 - last update), 08.00 PM, Penyelesaian Konflik Pertanahan pada Kawasan Pariwisata Lombok (Studi Kasus Tanah Terlantar di Gili Trawangan Lombok), Available: https://scholar. google. co.id/scholar?q=Asikin\%2C+Zainal.2014 
Vol. 5 No 1, 2017

Penyelesaian

+ Konflik+Pertanahan+pada+Kawasan+Pariwisata+

Lombok+\%28Studi+Kasus+Tanah+Terlantar+di+Gili

+Trawangan+Lombok\%29.+\&btnG=\&hl=id\&as_sdt= 0\%2C5. (Accessed: 2016, June 25).

Hartati. (2013, June 25 - last update), 08.15 PM, Pemanfaatan Objek Wisata Ceking Terrace Terhadap Pendapatan Masyarakat Di Kawasan Ceking Terrace Tahun 2013, Available :https:/scholar. google.co.id / scholar?= Hartati .+2013.+ Pemanfaa tan+ Objek + Wisata+Ceking+Terrace+Terhadap+Pendapatan $+\mathrm{Ma}$ syarakat+Di+Kawasan+Ceking+Terrace+Tahun+201 $\underline{3 .+ \text { Tersedia }+ \text { online }+ \text { pada }+\& b \operatorname{bth}=\quad \text { \&hl=id\&as }}$ sdt=0\%2C5 